\title{
THE RELATIONSHIP OF RENAL OXYGEN CONSUMPTION TO RENAL FUNCTION AND WEIGHT IN INDIVIDUALS WITH NORMAL AND DISEASED KIDNEYS*
}

\author{
By ARCHER P. CROSLEy, Jr., † CESAR CASTILlO and GEORGE G. ROWE $\ddagger$ \\ (From the Renal Section of the Department of Medicine and the Cardiovascular Research \\ Laboratory of the University of Wisconsin, Madison, Wis.)
}

(Submitted for publication April 4, 1960 ; accepted December 23, 1960)

In previous studies of renal oxygen consumption in man the results have been expressed in the following terms: $a$ ) the total oxygen consumed per two kidneys per minute $\left.\left(\mathrm{T}_{\mathrm{O}_{2}}\right)(1) ; b\right)$ the quantity of oxygen utilized per $100 \mathrm{~g}$ per minute based on the measurement of $\mathrm{TQ}_{\mathrm{O}_{2}}$ and an assumed weight of $300 \mathrm{~g}$ per two kidneys $(1) ; c$ ) the $\mathrm{T}_{\mathrm{O}_{2}}$ as related to total renal blood flow (TRBF) and glomerular filtration rate (GFR) (2). In the later instance Cargill and Hickam (2) concluded that $\mathrm{T}_{\mathrm{OO}_{2}}$ was best correlated with the GFR. Bradley and Halperin (3), on the other hand, suggested that the $\mathrm{T}_{\mathrm{O}_{2}}$ of the kidney was probably related to the "tubular functional mass" as determined by the tubular maximal secretory capacity for sodium para-aminohippurate $\left(\mathrm{Tm}_{\mathbf{P A H}}\right)$. However, as noted by Smith (4), no data have been forthcoming with regard to the latter relationship.

Therefore, the present paper is an attempt: 1) to provide data in which the relationship between the total renal oxygen consumption and the $\mathrm{Tm}_{\text {PAII }}$ is defined in normal subjects and in patients with kidney disease ; 2) to demonstrate the limitations of such a ratio $\left(\mathrm{T}_{\mathrm{QO}_{2}} / \mathrm{Tm}_{\mathrm{PAH}}\right)$; and 3 ) to suggest that in future studies $\mathrm{T}_{\mathrm{O}_{2}}$ be considered alone and/or that oxygen consumption be determined as $\mathrm{Q}_{\mathrm{o}_{2}}$ per $100 \mathrm{~g}$ per minute.

\section{MATERIAL AND METHODS}

Five "normal" 1 subjects, 5 patients with essential hypertension (grade 2-3), 5 with diabetic nephropathy, 5

* This research was supported by grants from the Wisconsin Heart Association, the Wisconsin Alumni Research Foundation, and the National Heart Institute ( $\mathrm{H}-1495$ and $\mathrm{H}-4263$ ).

$\dagger$ Present address: Renal Section, Hospital of The University of Pennsylvania, and the Department of Clinical Research, Mercy-Douglass Hospital, Philadelphia, $\mathrm{Pa}$.

$\ddagger$ Markle Fellow in Medicine.

1 "Normal" subjects were individuals diagnosed as having "psychoneurotic reaction" (000-X0Y). with chronic pyelonephritis, and 5 with chronic glomerulonephritis were selected from the wards of the University Hospitals between 1952 and 1958. In addition, one each of the following types of patients was studied as a "control": "juvenile" diabetes mellitus without clinical evidence of retinopathy or nephropathy; essential hypertension before and after the administration of oral glucose and intravenous insulin. In all cases the diagnoses were made on clinical rather than morphological grounds.

All patients, with the exception of those with diabetes mellitus, were studied in a fasting state. The exceptions were given their breakfast as a liquid glucose equivalent ${ }^{2}$ along with their daily dose of insulin 1 hour prior to the start of the test. Evidence that such a procedure did not appear to influence the results is presented in the Discussion.

Simultaneous determinations of glomerular filtration rate, total renal plasma flow (TRPF), TRBF, arteriorenal venous oxygen difference $\left(A-R_{O_{2}}\right), T_{Q_{2}}$, renal blood flow per $100 \mathrm{~g}$ per minute $(\mathrm{RBF})$, renal oxygen consumption per $100 \mathrm{~g}$ per minute $\left(\mathrm{Q}_{\mathrm{o}_{2}}\right)$, and in vivo renal weight $\left(R_{w t}\right)$ were made, utilizing right renal vein catheterization and techniques previously described for this laboratory $(5,6)$.

The results, contained in the tables, represent the average of three 15-minute periods. They are uncorrected for surface area since the relationships to be discussed did not lend themselves to correction and/or resulted in cancellation of this correction by virtue of being present in both the numerator and the denominator. Furthermore, the mean values for surface area of the 5 groups did not differ significantly from one another per meter $^{2}$ ("normals," 1.80 ; essential hypertension, 1.81; chronic glomerulonephritis, 1.80 ; diabetic nephropathy, 1.77 ; chronic pyelonephritis, 1.82).

Statistical analyses were performed, utilizing the standard $t$ test (7).

\section{RESULTS}

The results are presented in Tables I-III.

Table I contains the individual data. Table II represents the mean values for each function of

2 The liquid glucose equivalent was calculated as 100 per cent of the carbohydrate, 58 per cent of the protein, and 10 per cent of the fat which would have been consumed at breakfast. 
TABLE I

Individual renal and metabolic data *

\begin{tabular}{|c|c|c|c|c|c|c|c|c|c|c|c|c|c|c|}
\hline \multirow[b]{2}{*}{ Patient } & \multirow[b]{2}{*}{ GFR } & \multirow[b]{2}{*}{ TRBF } & \multirow[b]{2}{*}{$\mathrm{RBF}$} & \multirow[b]{2}{*}{$\mathrm{R}_{\mathrm{wt}}$} & \multirow[b]{2}{*}{ TmPAH } & \multirow{2}{*}{$\frac{\text { TmPAH }}{R_{w t}}$} & \multirow{2}{*}{$\frac{\mathrm{GFR}}{\mathrm{TmPAH}}$} & \multirow{2}{*}{$\frac{\mathrm{GFR}}{\mathrm{R}_{\mathrm{w} t}}$} & \multirow{2}{*}{$\frac{\text { TRBF }}{\text { TMPAH }}$} & \multirow{2}{*}{$\mathrm{A}-\mathrm{RVO}_{2}$} & \multirow[b]{2}{*}{$\mathrm{TQ})_{2}$} & \multirow[b]{2}{*}{$\mathrm{QO}_{2}$} & \multirow{2}{*}{$\frac{T_{\text {QO2 }}}{T_{\mathrm{mPAH}}}$} & \multirow{2}{*}{$\frac{\text { TQO2 }}{\mathrm{GFR}}$} \\
\hline & & & & & & & & & & & & & & \\
\hline & $m l / m i n$ & $m l / m i n$ & $\begin{array}{c}\mathrm{ml} / 100 \\
\mathrm{~g} / \mathrm{min}\end{array}$ & $g$ & $\mathrm{mg} / \mathrm{min}$ & $\underset{\mathrm{min} / \mathrm{g}}{\mathrm{mg}}$ & $m l i m g$ & $\underset{m i n / g}{m l /}$ & $m l / m g$ & $\mathrm{vol} \%$ & $\begin{array}{c}m l / 2 \\
\text { kidneys } \\
/ \text { min }\end{array}$ & $\begin{array}{c}\mathrm{ml} / \mathrm{100} \\
\mathrm{g} / \mathrm{min}\end{array}$ & $m l / m g$ & $m l / m l$ \\
\hline \multicolumn{15}{|l|}{ Normal } \\
\hline $\begin{array}{l}\text { M.F. } \\
\text { N.G. } \\
\text { K.T. } \\
\text { K.L. } \\
\text { R.S. }\end{array}$ & $\begin{array}{r}133 \\
91 \\
86 \\
81 \\
104\end{array}$ & $\begin{array}{r}1,800 \\
1,440 \\
1,255 \\
935 \\
1,505\end{array}$ & $\begin{array}{l}528 \\
300 \\
342 \\
302 \\
494\end{array}$ & $\begin{array}{l}342 \\
480 \\
368 \\
310 \\
305\end{array}$ & $\begin{array}{l}98 \\
88 \\
62 \\
88 \\
86\end{array}$ & $\begin{array}{l}0.29 \\
0.18 \\
0.17 \\
0.28 \\
0.28\end{array}$ & $\begin{array}{l}1.36 \\
1.03 \\
1.39 \\
0.91 \\
1.21\end{array}$ & $\begin{array}{l}0.390 \\
0.190 \\
0.243 \\
0.261 \\
0.341\end{array}$ & $\begin{array}{l}18.4 \\
16.3 \\
20.2 \\
10.5 \\
19.7\end{array}$ & $\begin{array}{l}1.3 \\
1.4 \\
1.2 \\
1.8 \\
1.4\end{array}$ & $\begin{array}{l}23.4 \\
20.2 \\
15.1 \\
16.8 \\
20.5\end{array}$ & $\begin{array}{l}6.9 \\
4.2 \\
4.1 \\
5.4 \\
6.8\end{array}$ & $\begin{array}{l}0.237 \\
0.236 \\
0.172 \\
0.191 \\
0.237\end{array}$ & $\begin{array}{l}0.176 \\
0.222 \\
0.176 \\
0.207 \\
0.197\end{array}$ \\
\hline \multicolumn{15}{|c|}{ Essential hypertension } \\
\hline $\begin{array}{l}\text { E.K. } \\
\text { L.A. } \\
\text { K.L. } \\
\text { S.R. } \\
\text { D.N. }\end{array}$ & $\begin{array}{l}51 \\
87 \\
90 \\
62 \\
57\end{array}$ & $\begin{array}{r}710 \\
1,215 \\
1,070 \\
630 \\
655\end{array}$ & $\begin{array}{l}410 \\
398 \\
303 \\
336 \\
426\end{array}$ & $\begin{array}{l}173 \\
305 \\
353 \\
188 \\
151\end{array}$ & $\begin{array}{l}60 \\
85 \\
88 \\
69 \\
63\end{array}$ & $\begin{array}{l}0.35 \\
0.28 \\
0.25 \\
0.37 \\
0.41\end{array}$ & $\begin{array}{l}0.85 \\
1.03 \\
1.03 \\
0.90 \\
0.91\end{array}$ & $\begin{array}{l}0.295 \\
0.285 \\
0.254 \\
0.329 \\
0.370\end{array}$ & $\begin{array}{r}11.8 \\
14.3 \\
12.2 \\
9.2 \\
10.4\end{array}$ & $\begin{array}{l}1.7 \\
1.2 \\
1.8 \\
2.1 \\
2.0\end{array}$ & $\begin{array}{l}12.1 \\
14.6 \\
19.3 \\
13.2 \\
13.1\end{array}$ & $\begin{array}{l}7.0 \\
4.8 \\
5.5 \\
7.1 \\
8.5\end{array}$ & $\begin{array}{l}0.203 \\
0.172 \\
0.219 \\
0.192 \\
0.218\end{array}$ & $\begin{array}{l}0.237 \\
0.168 \\
0.215 \\
0.213 \\
0.203\end{array}$ \\
\hline \multicolumn{15}{|c|}{ Chronic glomerulonephritis } \\
\hline $\begin{array}{l}\text { M.H. } \\
\text { D.K. } \\
\text { C.B. } \\
\text { D.A. } \\
\text { P.M. }\end{array}$ & $\begin{array}{l}52 \\
44 \\
87 \\
71 \\
15\end{array}$ & $\begin{array}{r}675 \\
755 \\
1,085 \\
1,110 \\
350\end{array}$ & $\begin{array}{l}307 \\
265 \\
279 \\
249 \\
300\end{array}$ & $\begin{array}{l}220 \\
285 \\
389 \\
446 \\
117\end{array}$ & $\begin{array}{r}47 \\
55 \\
101 \\
76 \\
19\end{array}$ & $\begin{array}{l}0.21 \\
0.19 \\
0.26 \\
0.17 \\
0.16\end{array}$ & $\begin{array}{l}1.11 \\
0.80 \\
0.86 \\
0.93 \\
0.79\end{array}$ & $\begin{array}{l}0.236 \\
0.154 \\
0.224 \\
0.159 \\
0.128\end{array}$ & $\begin{array}{l}14.4 \\
13.7 \\
10.8 \\
14.6 \\
18.4\end{array}$ & $\begin{array}{l}1.5 \\
1.0 \\
1.8 \\
1.2 \\
1.8\end{array}$ & $\begin{array}{r}10.1 \\
7.6 \\
19.5 \\
13.4 \\
6.3\end{array}$ & $\begin{array}{l}4.6 \\
2.7 \\
5.0 \\
3.0 \\
5.4\end{array}$ & $\begin{array}{l}0.215 \\
0.139 \\
0.197 \\
0.176 \\
0.331\end{array}$ & $\begin{array}{l}0.193 \\
0.173 \\
0.224 \\
0.189 \\
0.420\end{array}$ \\
\hline \multicolumn{15}{|c|}{ Diabetic nephropathy } \\
\hline $\begin{array}{l}\text { A.K. } \\
\text { W.F. } \\
\text { E.McM. } \\
\text { H.B. } \\
\text { M.W. }\end{array}$ & $\begin{array}{l}30 \\
19 \\
61 \\
44 \\
36\end{array}$ & $\begin{array}{l}455 \\
465 \\
790 \\
665 \\
640\end{array}$ & $\begin{array}{l}160 \\
144 \\
208 \\
233 \\
298\end{array}$ & $\begin{array}{l}284 \\
323 \\
378 \\
285 \\
230\end{array}$ & $\begin{array}{l}21 \\
25 \\
57 \\
35 \\
32\end{array}$ & $\begin{array}{l}0.07 \\
0.08 \\
0.15 \\
0.12 \\
0.14\end{array}$ & $\begin{array}{l}1.43 \\
0.76 \\
1.07 \\
1.25 \\
0.12\end{array}$ & $\begin{array}{l}0.106 \\
0.059 \\
0.162 \\
0.154 \\
0.157\end{array}$ & $\begin{array}{l}21.3 \\
18.6 \\
13.9 \\
19.0 \\
19.4\end{array}$ & $\begin{array}{l}1.2 \\
1.4 \\
2.1 \\
1.4 \\
1.3\end{array}$ & $\begin{array}{r}5.6 \\
6.5 \\
16.8 \\
9.3 \\
8.3\end{array}$ & $\begin{array}{l}2.0 \\
2.0 \\
4.4 \\
3.3 \\
3.9\end{array}$ & $\begin{array}{l}0.266 \\
0.260 \\
0.293 \\
0.265 \\
0.269\end{array}$ & $\begin{array}{l}0.187 \\
0.342 \\
0.275 \\
0.212 \\
0.230\end{array}$ \\
\hline \multicolumn{15}{|c|}{ Chronic pyelonephritis } \\
\hline $\begin{array}{l}\text { P.S. } \\
\text { W.H. } \\
\text { E.W. } \\
\text { R.G. } \\
\text { L.E. }\end{array}$ & $\begin{array}{l}30 \\
11 \\
41 \\
21 \\
27\end{array}$ & $\begin{array}{l}390 \\
210 \\
610 \\
300 \\
210\end{array}$ & $\begin{array}{r}157 \\
134 \\
189 \\
121 \\
63\end{array}$ & $\begin{array}{l}248 \\
157 \\
322 \\
247 \\
331\end{array}$ & $\begin{array}{l}30 \\
11 \\
47 \\
19 \\
18\end{array}$ & $\begin{array}{l}0.12 \\
0.07 \\
0.15 \\
0.08 \\
0.05\end{array}$ & $\begin{array}{l}1.00 \\
1.00 \\
0.87 \\
1.11 \\
1.05\end{array}$ & $\begin{array}{l}0.121 \\
0.070 \\
0.127 \\
0.085 \\
0.081\end{array}$ & $\begin{array}{l}13.0 \\
12.2 \\
13.0 \\
15.8 \\
11.7\end{array}$ & $\begin{array}{l}2.1 \\
1.3 \\
1.5 \\
1.9 \\
4.1\end{array}$ & $\begin{array}{l}8.2 \\
2.7 \\
9.2 \\
5.7 \\
8.6\end{array}$ & $\begin{array}{l}3.2 \\
1.7 \\
2.8 \\
2.3 \\
2.6\end{array}$ & $\begin{array}{l}0.273 \\
0.245 \\
0.195 \\
0.300 \\
0.486\end{array}$ & $\begin{array}{l}0.272 \\
0.245 \\
0.224 \\
0.272 \\
0.318\end{array}$ \\
\hline
\end{tabular}

* See text for abbreviations.

any given group, the standard errors of such means, as well as the level of statistical significance (p) when the mean of a given function in a particular disease group is compared with the mean of the corresponding function of the "normal" individuals. The material contained in Table III has been reserved for the Discussion.

Normal. The results obtained in such individuals were in accord with those previously reported from this $(5,6)$ and other laboratories (4). The values for GFR may be questioned as being normal. However, "normal" mean values given by other investigators, using the inulin clearance technique, with $\mathrm{PAH}$ at low plasma levels, have ranged between 114 and $140 \mathrm{ml}$ per minute with standard deviations of \pm 4.4 to $\pm 40 \mathrm{ml}$ per minute (4). Also, the GFR's presented in Table I were obtained at the same time as the determinations of $\mathrm{Tm}_{\mathrm{PAH}}$. The latter procedure, based on 30 different investigations in as many patients, produced a decrease in GFR of 19 per cent (8) over those obtained before PAH satu- ration. This is in accord with previous observations (4).

Essential hypertension. A comparison of the data of these patients with those obtained in "normal" subjects shows that GFR $(p<0.05)$, TRBF $(p<0.02)$, and the $\mathrm{TQO}_{2}(\mathrm{p}<0.05)$ were significantly reduced. In contrast, the $A-R_{O_{2}}(p>0.2)$, the RBF per $100 \mathrm{~g}$ per minute $(p>0.7)$, as well as the renal $Q_{o_{2}}$ per $100 \mathrm{~g}$ per minute $(p>0.3)$ were not significantly different from normal. The decline in TRBF and $\mathrm{T}_{\mathrm{O}_{2}}$, as compared with the lack of change in these functions when expressed on a unit weight basis, is probably related to the significant reduction in renal weight $(p<0.05)$. The mean value for $T m_{P A H}$ was $11 \mathrm{mg}$ per minute less than the mean value for this function in normal subjects, but this difference was not statistically significant $(\mathrm{p}>0.12)$.

The ratio of the $\mathrm{T}_{\mathrm{QO}_{2}}$ to the $\mathrm{Tm}_{\mathrm{PAH}}$ or to the GFR remained unaltered $(p>0.3$ in both instances). The significant decrease in TRBF/ 


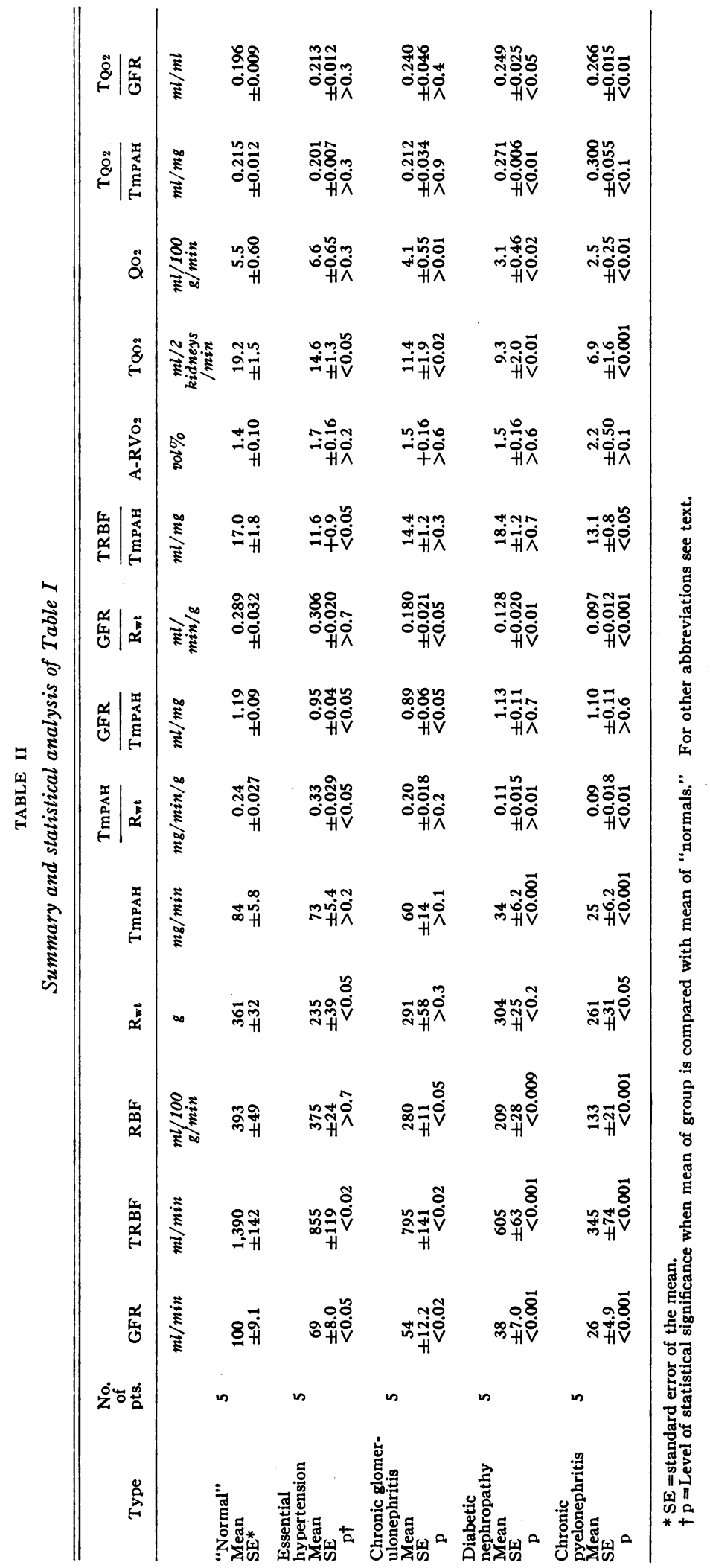


TABLE III

Control studies

\begin{tabular}{|c|c|c|c|c|c|c|c|c|c|}
\hline Patient no. & GFR & TRBF & TMPAH & $\frac{\text { GFR }}{\text { TmPAH }}$ & $\frac{\text { TRBF }}{\text { TmPAH }}$ & $\mathrm{A}-\mathrm{RVO}_{2}$ & $\mathrm{TQO}_{2}$ & $\frac{\text { TQO2 }}{\text { TMPAH }}$ & $\frac{\mathrm{TQO}_{2}}{\mathrm{GFR}}$ \\
\hline & $\mathrm{ml} / \mathrm{min}$ & $\mathrm{ml} / \min$ & $m g / m i n$ & $\mathrm{ml} / \mathrm{min}$ & $\mathrm{ml} / \mathrm{min}$ & vol\% & $\begin{array}{c}m l / 2 \\
\text { kidneys } \\
/ \min \end{array}$ & $\mathrm{ml} / \mathrm{mg}$ & $\mathrm{ml} / \mathrm{ml}$ \\
\hline $\begin{array}{l}\text { 1. Diabetes } \\
\text { mellitus without } \\
\text { nephropathy }\end{array}$ & 65 & 865 & 72 & 0.90 & 12.0 & 1.8 & 15.6 & 0.216 & 0.240 \\
\hline $\begin{array}{l}\text { 2. Essential } \mathrm{C}^{*} \\
\text { hypertension } \\
\mathrm{E} \dagger\end{array}$ & $\begin{array}{l}58 \\
53\end{array}$ & $\begin{array}{l}740 \\
650\end{array}$ & $\begin{array}{l}49 \\
49\end{array}$ & $\begin{array}{l}1.14 \\
1.08\end{array}$ & $\begin{array}{l}15.1 \\
13.3\end{array}$ & $\begin{array}{l}1.4 \\
1.5\end{array}$ & $\begin{array}{r}10.4 \\
9.8\end{array}$ & $\begin{array}{l}0.213 \\
0.200\end{array}$ & $\begin{array}{l}0.178 \\
0.185\end{array}$ \\
\hline
\end{tabular}

* Control, fasting.

† Thirty to 60 minutes after $0.1 \mathrm{U}$ insulin $/ \mathrm{kg}$ i.v., plus $100 \mathrm{~g}$ glucose p.o.

$\operatorname{Tm}_{\mathrm{PAH}}(\mathrm{p}<0.05)$ and the constancy of the GFR/ $\mathrm{R}_{\mathrm{wt}}(\mathrm{p}>0.7)$ were expected, in view of the fact that the pathological changes in such kidneys are primarily of a vascular nature. In contrast, the significant reduction in GFR/T $\mathrm{m}_{\mathrm{PAH}}(\mathrm{p}<0.05)$, and the increase in $\mathrm{Tm}_{\mathrm{PAH}} / \mathrm{R}_{\mathrm{wt}}(\mathrm{p}<0.05)$, were unexpected findings. A possible explanation for these observations is presented in a later section.

Chronic glomerulonephritis. As in patients with essential hypertension, the GFR $(p<0.02)$ and TRBF $(\mathrm{p}<0.02)$ were significantly decreased. However, when these functions were related to the $T \mathrm{~m}_{\mathrm{PAH}}$, a significant reduction was noted in GFR/Tm $\mathrm{T}_{\mathrm{PAH}}(\mathrm{p}<0.05)$, while TRBF/ $\mathrm{Tm}_{\mathrm{PAH}}$ remained unchanged $(\mathrm{p}>0.3)$. Furthermore, there was a fall in GFR/ $R_{w t}(p<0.05)$. Such findings indicated the primary glomerular involvement in this entity. The absence of a change in $T R B F / T m_{P A H}(p>0.3)$, despite significant reductions in TRBF $(p<0.02)$ as well as RBF per $100 \mathrm{~g}$ per minute $(\mathrm{p}<0.05)$, is interpreted to mean that the fall in renal blood flow was proportionate to the progressive renal damage in this disease.

$\mathrm{Tm}_{\mathrm{PAH}} / \mathrm{R}_{\mathrm{wt}}$ remained unchanged $(\mathrm{p}>0.1)$ while all of the other estimations were similar to those found in the individuals with essential hypertension.

Diabetic nephropathy. The features which distinguished this group of patients from "normal," as compared with the groups with essential hypertension and glomerulonephritis, were the significant reductions noted in $\operatorname{Tm}_{\mathrm{PAH}}(\mathrm{p}<0.001)$, $\mathrm{Tm}_{\mathrm{PAH}} / \mathrm{R}_{\mathrm{wt}}(\mathrm{p}<0.01), \mathrm{Q}_{\mathrm{O}_{2}}$ per $100 \mathrm{~g}$ per minute $(p<0.02)$ and the significant increases in
$\mathrm{T}_{\mathrm{QO}_{2}} / \mathrm{Tm}_{\mathrm{PAH}}(\mathrm{p}<0.01)$ and $\mathrm{T}_{\mathrm{QO}_{2}} / \mathrm{GFR}(\mathrm{p}<$ 0.05). Furthermore, GFR/Tm $\mathrm{m}_{\mathrm{PAH}}$ and TRBF/ $\mathrm{Tm}_{\mathrm{PAH}}$, which heretofore, either alone or in combination were significantly altered, remained unchanged in these individuals.

Chronic pyelonephritis. Patients in this group, with two exceptions, were similar from both functional and metabolic standpoints to the patients with diabetic nephropathy. First, although the mean value for $\mathrm{T}_{\mathrm{QO}_{2}} / \mathrm{Tm}_{\mathrm{PAH}}$ was increased to an even greater extent $(0.300 \mathrm{ml}$ per $\mathrm{mg})$ than that observed in the patients with diabetic nephropathy $(0.271 \mathrm{ml}$ per $\mathrm{mg})$ it was nevertheless not found to be statistically different from normal, due to the variability of the individuals within the group. Secondly, $\mathrm{T}_{\mathrm{QO}_{2}} / \mathrm{GFR}$ was significantly increased $(\mathrm{p}<0.01)$.

\section{DISCUSSION}

It is obvious that the renal $\mathrm{T}_{\mathrm{O}_{2}}$ represents the sum of the oxygen consumed by the individual parts of the kidney. However, in the past, efforts have been made to relate the former quantity of oxygen to one functional measurement [e.g., $\operatorname{TRBF}(9,10), \operatorname{GFR}(2)]$. Therefore, since it was conceivable that $\mathrm{T}_{\mathrm{O}_{2}}$ might be primarily related to TRBF, to the "tubular functional mass" or to glomerular function and, since all of these functions have not heretofore been measured simultaneously in patients with "normal" and diseased kidneys (4), the present study was undertaken in an effort to test whether such a primary relationship existed.

Total renal blood flow. Van Slyke, Rhoads, Hiller and Alving (9), as well as others (10), 
initially concluded that the total renal oxygen consumption was related to the total renal blood flow. Subsequent studies by Clark and Barker (1) and Barker and Crosley and co-workers (11-13), utilizing measures which alter total renal blood flow, showed that such was not the case in normal human subjects or in patients with renal disease. Thus the arterio-renal venous oxygen difference could indeed narrow or widen in response to change in blood flow, thereby maintaining an unchanged oxygen consumption. Furthermore, since $\mathrm{T}_{\mathrm{O}_{2}}$ is derived as the product of TRBF and the arterio-renal venous oxygen difference, one would predict a high correlation between $\mathrm{TRBF}$ and $\mathrm{T}_{\mathrm{O}_{2}}$ on a purely mathematical basis. In addition, it follows that the narrower the range of the arterio-renal venous oxygen differences the higher the correlation. In the present study this range was so narrow that there was no significant difference between the arterio-renal venous oxygen differences of the diseased groups and those of the "normals"; hence a correlation between $\mathrm{TRBF}$ and $\mathrm{T}_{\mathrm{QO}_{2}}$ was not considered applicable.

"Tubular functional mass." Although it had been suggested by Bradley and Halperin (3) that the most likely relationship between the $\mathrm{T}_{\mathrm{O}_{2}}$ and the renal functional elements was between $\mathrm{T}_{\mathrm{O}_{2}}$ and the "tubular functional mass" ( $\mathrm{T}_{\mathrm{QO}_{2}} /$ $\mathrm{Tm}_{\mathrm{PAH}}$ ), no data on this ratio have been forthcoming until the present study (4). Support for such a relationship is the finding here that the correlation between these two factors is highly significant $(R=+0.923, p<0.001)$.

Glomerular filtration rate. As previously noted, Cargill and Hickam (2) reported a positive correlation between the total oxygen consumption of the kidney and the glomerular filtration rate. On the surface, such findings pose the problem as to why oxygen consumption should be related to a function whose primary energy source is that of the net hydrostatic pressure of the blood. However, recent evidence by Dubach and Recant (14) lend support to such a relationship, since their in vitro investigations of individual glomeruli attribute important oxidative functions to this structure. The present data are also in accord with the concept that total oxygen consumption is related to glomerular activity, since the correlation coefficient between these two functions, utilizing all of the patients in the five groups, was $\mathrm{R}=+0.955(\mathrm{p}<0.001)$.

In view of the highly significant correlation coefficients for both GFR and $\mathrm{Tm}_{\mathrm{PAH}}$ as related to $\mathrm{T}_{\mathrm{O}_{2}}$ it appears that one explanation for such data is that, in renal disease, there is a symmetrical destruction of both glomeruli and tubules and that associated with the loss of such nephrons there is a proportionate reduction in $\mathrm{T}_{\mathrm{Qo}_{2}}$. Such a statement would be in agreement with the findings of Bricker, Morrin and Kime in unilaterally induced renal disease in dogs, which appear to demonstrate proportionate declines in glomeruli and tubules (15). An alternative explanation would be that suggested by Cargill and Hickam (2), that tubular activity is largely governed by the quantity of glomerular filtrate and thus a close correlation between GFR, $\mathrm{Tm}_{\mathrm{PAH}}$ and $\mathrm{T}_{\mathrm{O}_{2}}$ might be expected.

Finally, the unexpected findings of the increased

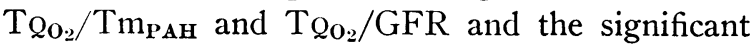
decreases in $T m_{\mathbf{P A H}} / \mathrm{R}_{\mathrm{wt}}$ in patients with diabetic nephropathy and chronic pyelonephritis, as well as the decreased GFR/Tm $\mathrm{TAH}_{\mathbf{P A}}$ in essential hypertension, must be considered. No definitive explanation is forthcoming for any of these results.

However, in the case of the increased $\mathrm{T}_{\mathrm{Q}_{2}}$ / $\mathrm{Tm}_{\mathrm{PAH}}$ and $\mathrm{T} \mathrm{Q}_{\mathrm{O}_{2}} / \mathrm{GFR}$ in patients with diabetic nephropathy and chronic pyelonephritis, these changes do not appear to be due to: $a$ ) the diabetic state per se, since they occurred in patients without diabetes (e.g., chronic pyelonephritis and Patient P.M. with glomerulonephritis); $b$ ) the presence of insulin and/or the glucose-equivalent breakfast, since a control diabetic patient (Table III, no. 1) and a nondiabetic patient (no. 2) given a "glucose-insulin" tolerance test did not show elevations of these ratios; $c$ ) the oxygen consumption of nonexcretory renal tissue (e.g., scar tissue), since the $Q_{\mathrm{O}_{2}}$ of such tissue is lower than that of excretory renal tissue (16). In view of the significant decreases in $Q_{\mathrm{O}_{2}}$ per $100 \mathrm{~g}$ per minute associated with the increased $\mathrm{T}_{\mathrm{Q}_{2}} / \mathrm{Tm}_{\mathrm{PAH}}$ and $\mathrm{T}_{\mathrm{O}_{2}} / \mathrm{GFR}$, one can only speculate that the latter findings may be related to the fact that a total quantity (oxygen) was related to only a part ( $\mathrm{Tm}_{\mathrm{PAH}}$ and/or GFR) of the total metabolizing tissue of the kidney $\left(\mathrm{Tm}_{\mathrm{PAH}}\right.$ and/or GFR plus scar and exudative tissue). In a similar 
fashion, one can only hypothesize that the significant depression in $\mathrm{Tm}_{\mathrm{PAH}} / \mathrm{R}_{\mathrm{wt}}$, in these cases, may be due to the fact that a significant portion of the kidney weight was composed of nonexcretory renal tissue (scar tissue). If so, the ratio $T \mathrm{~m}_{\mathbf{P A B}} /$ $\mathrm{R}_{\mathrm{wt}}$ may serve as an index of renal "scarring."

The observation of a significant decrease in GFR/Tm $\mathrm{TAH}_{\mathrm{PA}}$ in patients with essential hypertension has not been the usual finding in other series (4). Such data may be fortuitous, since the number of patients was small and the significance was borderline $(p<0.05)$. However, a recent report by Baldwin and associates (17) in patients with essential hypertension revealed a decline in the GFR/T $\mathrm{m}_{\mathrm{PAH}}$ in the majority of the cases. Furthermore, White, Sambhi and Grollman have reported such findings in experimentally induced hypertension in rats (18).

\section{SUMMARY AND CONCLUSIONS}

1. A number of observations was made in individuals with "normal" and diseased kidneys in an effort to determine whether any single functional component [total renal blood flow (TRBF), glomerular filtration rate (GFR), "tubular functional mass" $\left(\mathrm{Tm}_{\mathrm{PAH}}\right)$ ] was a primary contributor to the total oxygen consumed per two kiclneys per minute $\left(\mathrm{T}_{\mathrm{O}_{2}}\right)$. None could be found.

2. Since in certain disease categories (diabetic nephropathy and chronic pyelonephritis) $\mathrm{T}_{\mathbf{Q O}_{2} /}$ $\mathrm{Tm}_{\mathrm{PAH}}$ or $\mathrm{T}_{\mathrm{QO}_{2}} / \mathrm{GFR}$ was increased, while at the same time $\mathrm{T}_{\mathrm{O}_{2}}$ and renal oxygen consumption per $100 \mathrm{~g}$ per minute $\left(\mathrm{Q}_{\mathrm{O}_{2}}\right)$ were decreased, it is suggested that in future studies $\mathrm{T}_{\mathrm{Q}_{2}}$ be considered alone or, if a base reference is desired, that renal oxygen consumption be determined in terms of $Q_{0.2}$ per $100 \mathrm{~g}$ per minute.

3. $T m_{P A H} / R_{w t}$ was significantly reduced in patients with chronic pyelonephritis and diabetic nephropathy, while the GFR/T $\mathrm{m}_{\mathbf{P A B}}$ was reduced in essential hypertension. No definitive explanation is forthcoming for such findings.

\section{ACKNOWLEDGMENT}

The authors would like to acknowledge the help of Drs. C. W. Crumpton, B. Schuster, R. McKenna, J. Brown, D. Freeman, J. H. Husten and R. Cullen who periodically aided in the course of this investigation
(1952-1958). Acknowledgment also is made to Mrs. P. Fosshage and Mrs. A. Peterson and co-workers for their technical contributions.

\section{REFERENCES}

1. Clark, J. K., and Barker, H. G. Studies of renal oxygen consumption in man. I. The effect of tubular loading $(\mathrm{PAH})$, water diuresis and osmotic (mannitol) diuresis. J. clin. Invest. 1951, 30, 745.

2. Cargill, W. H., and Hickam, J. B. The oxygen consumption of the normal and the diseased human kidney. J. clin. Invest. 1949, 28, 526.

3. Bradley, S. E., and Halperin, M. H. Renal oxygen consumption in man during abdominal compression. J. clin. Invest. 1948, 27, 635.

4. Smith, H. W. The Kidney: Structure and Function in Health and Disease. New York, Oxford Univ. Press, 1951.

5. Crosley, A. P., Jr., and Crumpton, C. W. Contribution of intracardiac catheterization to studies of renal physiology and disease in Intravascular Catheterization, H. A. Zimmermann, Ed. Springfield, Ill., C. C Thomas, 1959, p. 461.

6. Crosley, A. P., Jr., Brown, J. F., Huston, J. H., Emanuel, D. A., Tuchman, H., Castillo, C., and Rowe, G. G. The adaptation of the nitrous oxide method to the determination of renal blood flow and in vivo renal weight in man. J. clin. Invest. 1956, 35, 1340.

7. Fisher, R. A. Statistical Methods for Research Workers, 13th ed. New York, Hafner, 1958.

8. Crosley, A. P., Jr., Barker, E. S., and Clark, J. K. Unpublished data.

9. Van Slyke, D. D., Rhoads, C. P., Hiller, A., and Alving, A. S. Relationships between urea excretion, renal blood flow, renal oxygen consumption, and diuresis. The mechanism of urea excretion. Amer. J. Physiol. 1934, 109, 336.

10. Kramer, K., and Winton, F. R. The influence of urea and of change in arterial pressure on the oxygen consumption of the isolated kidney of the dog. J. Physiol. (Lond.) 1939, 96, 87.

11. Barker, H. G., Clark, J. K., Crosley, A. P., Jr., and Cummins, A. J. The effect of salt poor human albumin on renal oxygen consumption in man (abstract). Amer. J. Med. Sci. 1949, 218, 715.

12. Crosley, A. P., Jr., Barker, H. G., and Clark, J. K. The effects of headup tilt on the hemodynamics and metabolism of the human kidney (abstract). Proc. Amer. Fed. clin. Res. May, 1951.

13. Crosley, A. P., Jr., Rowe, G. G., and Crumpton, C. W. The hemodynamic and metabolic response of the human hypertensive kidney to a standard dose of 1-hydrazinophthalazine (hydralazine). J. Lab. clin. Med. 1954, 44, 104.

14. Dubach, U. C., and Recant, L. Enzymatic activity of the isolated glomerulus in normal and nephrotic 
rats (abstract). J. Lab. clin. Med. 1959, 54, 17. Baldwin, D. S., Hulet, W. H., Biggs, A. W., Gom808.

15. Bricker, N. S., Morrin, P. A. F., and Kime, S. W., Jr. The pathologic physiology of chronic Bright's disease. An exposition of the "intact nephron hypothesis." Amer. J. Med. 1960, 28, 77.

16. Gemmill, C. L. Metabolism and nutrition in Macleod's Physiology in Modern Medicine, P. Bard, Ed., 9th ed. St. Louis, C. V. Mosby, 1941, p. 711. bos, E. A., and Chasis, H. Renal function in the separate kidneys of man. II. Hemodynamics and excretion of solute and water in essential hypertension. J. clin. Invest. 1960, 39, 395.

18. White, F. N., Sambhi, M. P., and Grollman, A. Renal function in hypertensive cardiovascular disease of rat. Amer. J. Physiol. 1960, 198, 221. 